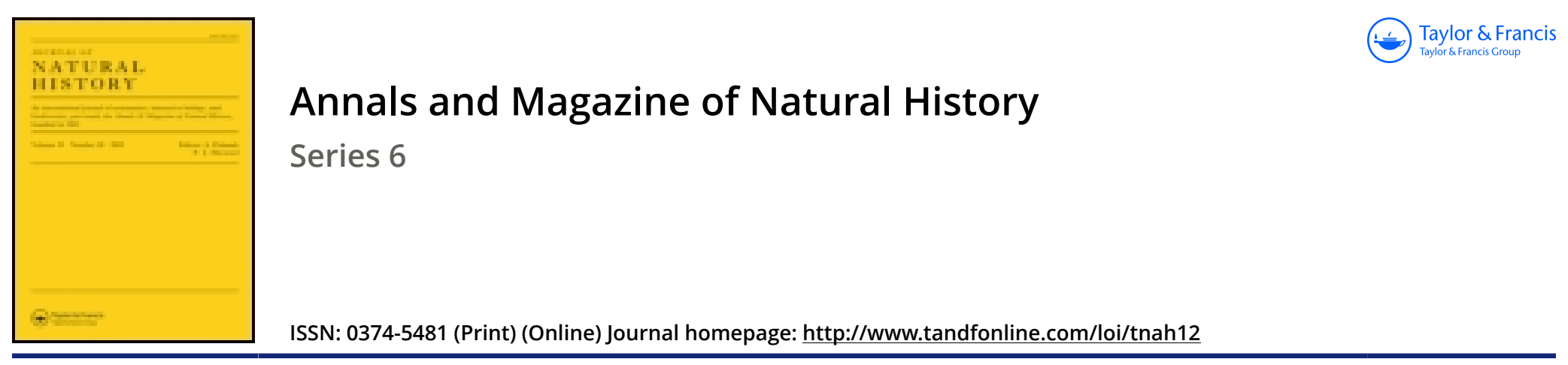

\title{
XIV.-Notes on some shells recently received by the British Museum
}

\section{Edgar A. Smith}

To cite this article: Edgar A. Smith (1891) XIV.-Dotes on some shells recently received by the British Museum , Annals and Magazine of Natural History, 7:37, 135-140, DOI: 10.1080/00222939109460586

To link to this article: http://dx.doi.org/10.1080/00222939109460586

曲 Published online: 12 Oct 2009.

Submit your article to this journal $\sqsubset \pi$

Џ Article views: 2

Q View related articles 두 
Hind wing entirely smoky brown, with a very broad hind marginal border of dark brown, relieved by a row of white spots on the fringe, and a subterminal row of eight white spots varying very much in size. A yellow patch at the anal angle is also visible, though much darker in colour.

The underside is very similar to the upperside in markings, though the general colour is rather paler.

$H a b$. Ogowé River, Gaboon, (J. W. Jones).
Hind wing entirely white, with a border of brownish black on the hind margin. On this border is a subterminal row of white spots, as on the fore wing, with the exception of another row of white spots on the fringe, this row being very distinct on the hind wing. On the fore wing there are only four white spots commencing from the posterior angle. A yellow patch above this black hind marginal border is very distinct, and in some specimens extends to the middle of the wing, while the other half is pure white.

\section{XIV.-Notes on some Shells recently received by the British Museum. By Edgar A. Smith.}

From time to time the British Museum has been indebted to Mr. John Brazier, of Sydney, for very valuable donations of Mollusca and other specimens. A recent consignment contains a series of interesting species, upon some of which I have made the following notes. I also add descriptions of such as appear to be new, and finally append a list of the species of Land-shells at present known from Woodlark Island and the D'Entrecasteaux Group. I also take this opportunity of mentioning an omission in my paper on the land and freshwater shells of the Louisiade Archipelago, published in the 'Annals' for September 1889. Helix diomedes of Brazier *, unfortunately, was not referred to.

\section{Pupinella Angasi (Brazier).}

Pupina Angasi, Brazier, Proc. Linn. Soc. N. S. W. vol. i. p. 5.

Pupinella louisiadensis, Smith, Ann. Mag. Nat. Hist. 1889, vol. iv. p. 204, pl. xiii. figs. 3,4 .

Hab. New Guinea (Brazier olim); Rossel Island, Louisiade Group (Brazier in litt. and Thomson).

I described this species under the name of $P$. louisiadensis,

* Proc. Linn. Soc. N. S. W. vol. ii. p. 121. 
being ignorant of Mr. Brazier's paper in the Proc. Limn. Soc. N. S. Wales.

Mr. Brazier has kindly called my attention to his description, and sent a splendid series of specimens (including the actual types) of his Pupina Angasi, which at once proves its identity with $P$. louisiadensis.

Another species of Pupinella from the Louisiade Archipelago has also received the name Anqasi. This species was described by H. Adams in the Proc. Zool. Soc. for 1875 . His description was read in April and published in August. Mr. Brazier's species appears to take a few months' priority, and must therefore be retained; the description was read in January of the same year, and published (so I am informed by Mr. Brazier) the following May. Under these circumstances I have much pleasure in adopting for the shell described by Adams the name " Pupinella Smithï, Brazier," as kindly suggested by Mr. Brazier in a letter dated April 15th of this year.

\section{Pupinella Brazierce (Smith).}

Megalomastoma Braziera, Smith, Ann. Mag. Nat. Hist. 1888, vol. xix. p. 424 , pl. xv. fig. 15 .

Hab. Ferguson Island and Cape Pierson, Normanby Island, D'Entrecasteaux group, south-east of British New Guinea.

Since describing this species, I have had an opportunity of examining a series of specimens of the genus Pupinella from the Louisiade Islands, which shows that the characteristic notches in the labrum vary considerably in depth and other respects in species otherwise very much alike.

Quite a transition from a largely developed loop-like slit on the columellar side to a mere indication of a notch is observable in P. grandis, Macgregori, minor, Smithii, Moulinsiana, Angasi (Brazier), and Rosseliana. The study of these forms now points to the conclusion that the present species should also be located in the genus Pupinella, and not in Megalomastoma. The labral notch may be said to have entirely disappeared in this species, wbich, however, still possesses certain characters in common with several of the other species, namely, the uniform reddish colour, the wellthickened reflexed peristome, which is united to the bodywhorl above in the same manner, the circum-umbilical rilge or keel, and the sudden descent and contraction of the bodywhorl near the aperture. 
3. Helix (Geotrochus) woodlarkiana (Souverbie).

Hub. Woodlark Island (Souverbie), Normanby Island, D'Hintrecasteaux Group (Brazier).

The three specimens sent by Mr. Brazier from the above locality differ in markings. All, however, are similar in form, and agree in having the characteristic brownish or violet stain at the upper part of the reflexed columella. One specimen is waxy white, varied with opaque creamy white, interrupted, obliquely arcuate streaks upon the upper part of the body-whorl, and the spiral zones, as described in the type, are only faintly noticeable. The peristome in this example is of a brown flesh-tint, in the two other specimens it is white. Souverbie's figure does not at all well show the pretty interrupted bands which ornament the upper surface. The keeled periphery appears to be constantly white.

\section{Helix (Geotrochus) Boyeri, Fischer \& Bernardi.}

$H a b$. Admiralty Islands ( $F . \& B$. ) ; Louisiade Archipelago (Angas); east end of Woodlark Island (Brazier).

Two-specimens from Woodlark lsland evidently beloug to this species, but are differently coloured from the type. One is uniformly very light brown, with the exception of the white lip and a small lilac stain in the umbilical region. The other is cream-white, with two spiral brown bands, of which one above the periphery is a little broader than the other below it, and revolves up the spire. The slight prominence on the inner columellar edge shown in the figure is only present in one of the specimens at hand.

\section{Helix (Papuina) albocarinata, Smith.}

$H a b$. South Cape, British New Gruinea; also east end of Woodlark Island (Brazier).

The two specimens from Woodlark Island undoubtedly belong to this species. They agree in every particular with the type, excepting that one has a few narrow interrupted opaque white zones on the upper as well as the lower surface, whereas the other has none, being uniformly semipellucid, with the exception of the opaque keel at the periphery. This spccimen also is a trifle less elevated than the type. All have the yellowish stripe behind the slightly expanded lip.

\section{Helix (Hadra) bourkensis, sp. n.}

Testa anguste umbilicata, depresse globosa, subtenuis, nitida, flavescens, zonis duabus rufo-fuseis supra medium ornata ; anfractus 
$5 \frac{1}{2}$, convexiusculi, sublente accrescentes, sutura subprofunda sejuncti, incrementi lineis tenuibus striati, superne minute granulati, ultimus antice vix descendens, ad peripheriam rotundatus, inferne quam supra nitidior, haud granulatus; spira brevis ad apicem obtusa; apertura late lunata, pallide fuscescens, zona lata saturatiore superne ornata; peristoma tenue, pallidum, leviter expansum, margine columellari dilatato et reflexo, umbilicum semiobtegente.

Diam. maj. 20 millim., min. $17 \frac{1}{2}$, alt. $14 \frac{1}{2}$; apertura 10 longa, $9 \frac{1}{2}$ lata.

$H a b$. Bourke, Darling River, New South Wales (Brazier). This species in general appearance is considerably like $H$. Broughami, Angas, and H. Angasiana, Pfeiffer. The banding is exactly the same as that of the latter species, but its epidermis is yellower. It is also distinguished by its less globose form, smaller body-whorl, its more glossy surface, especially the under surface, the much smaller umbilicus and much thinner peristome, and a different granular sculpture on the spire. H. Broughami has an additional brown band below the periphery, has a finer granulation above, the umbilicus is more open and surrounded by a coloured zone, and the aperture is wider. H. Stutchburyi, Pfr., is a smaller form, more finely granular above, and in the type the spiral zones are much narrower than in the present and the two above-named species.

\section{Helicina woodlarkensis, sp. n.}

Testa parva, breviter trochiformis, solidiuscula, pallide corneo-lutea, concolor, inferne nitidior quam supra, undique spiraliter tenuiter sulcata, lineis incrementi obliquis striata; anfract. 5 , celeriter crescentes, subplani, uitimus in medio acute angulatus, infra convexiusculus, callo basali pellucido munitus ; spira breviter conica, ad apicem haud acuta; apertura subobliqua, longit. totius $\frac{2}{3}$ fere aquans; peristoma pallidum, mediocriter expansum, operculum fere album, externe leviter concavum.

Alt. 6 millim., diam. maj. $8 \frac{1}{3}$, min. 7 ; apertura $3 \frac{2}{3}$ longa, 3 lata.

Hab. Woodlark Island (Brazier).

This species in form and sculpture is very like $H$. reticulata, Pfr. It is, however, somewhat larger, has no variegated markings, the outer lip is more expanded, and the operculum is differently coloured. HI. reticulata occurs at Cape York and other places in North-east Australia. The "Cape Flattering," mentioned by Sowerby *, should of course be Cape Flattery on the North Queensland coast. His figure of that species represents the spire rather too much raised.

* Thesaurus Cou. vol. iii. pl. vii. ff. 231-2. 


\section{Scalaria ballinensis, sp. $\mathrm{n}$.}

Testa elongata, pyramidalis, imperforata, lævigata, haud costulata, albida vel pallide fuscescens, paulo nitida; anfractus normales 9 , mediocriter convexi, regulariter sublente accrescentes, lineis incrementi conspicuis obliquis, hic illic subvariciformibus, striisque spiralibus tenuibus subobsoletis sculpti, superne ad suturam leviter obliquam irregulariter crenulati, ultimus circa medium porca obtusa angulatus ; apertura parva, ovato-circularis, longit. totius $\frac{1}{4}$ adæquans ; colnmella obliqua, inferne incrassata, subeffusa; labrum vix incrassatum.

Longit. 17 millim., diam. $6 \frac{1}{3}$; apertura $4 \frac{1}{4}$ longa, 3 lata.

Hab. Ballina, near mouth of the Richmond River, New South Wales.

This species is remarkable on account of the smoothness of the whorls and the absence of ribs so characteristic of Scalaria. Of the four specimens presented to the British Museum by Mr. Brazier, one only presents any colouring. The total whiteness of the remaining three may be due to bleaching, as they appear to be dead shells. The coloured example is pale brown, crossed here and there by a few oblique whitish lines or pseudo-varices, which evidently mark periods of growth. Behind the outer lip and parallel with it is an orange stripe, particularly noticeable within the aperture. The apex of all the specimens being broken away, I am unable to describe the nuclear whorls. The form and proportion of the whorls of this species are fairly well illustrated by Sc. (Acirsa) borealis, Beck.

\section{List of Land-Shells of Woodlark Island.}

1. Helix (Geotrochus) woodlarkiana, Souverbie.

FIelix (Geotrochus) woodlarkinna, Souverbie, Journ. de Conch. 1863, pp. 76, 172, pl. v. f. 2 .

Hab. Woodlark Island (Souverbie).

2. Helix (Geotrochus) Boyeri, Fischer \& Bernardi.

Helix (Geotrochus) Boyeri, Fischer \& Bernardi, Journ. de Conch. 1856, vol. v. p. 297, pl. 9. ff. 8, 9.

Hab. Woodlark Island (Brazier).

3. Helic (Papuina) albocarinata, Smith.

Helix (Papuina) albocarinata, Smith, Ann. Mag. Nat. Hist. 1887, vol. xix. p. 422, pl. xv. f. 12.

Hab. Woodlark Island (Brazier). 
4. Partula similaris, Hartmann.

Partula similaris, Hartmann, Proc. Acad. Nat. Sci. Philad. 1886, p. 30.

Hab. Woodlark Island (Brazier).

5. Partula woodlarkiana, Hartmann.

Partula woodlarkiana, Hartmann, Proc. Acad. Nat. Sci. Philad. 1886, p. 33.

Hab. Woodlark Island (Brazier).

6. Pupina Moulinsiana, Fischer \& Bernardi.

Pupina Moulinsiana, Fischer \& Bernardi, Journ. de Conch. 1857, vol. v. p. 299 , pl. ix. ff. 6,7 .

Hab. Woodlark Island (Montrouzier \& Brazier).

7. Helicina Fischeriana, Montrouzier.

Helicina Fischeriana, Montrouzier, Journ. de Conch. 1863, pp. 76, 171, pl. v. f. 3.

Hab. Woodlark Island (Montrouzier).

8. Helicina woodlarkensis, sp. n.

Hab. Woodlark Island (Brazier).

Species from the D'Entrecasteaux Group.

In the Annals and Mag. Nat. Hist. 1883, vol. xi. p. 191, I described four species of Helix, viz. H. oxystoma, H. latiaxis, H. Tapparonii, and $H$. Gerrardi, as coming from this group of islands.

Mr. Brazier, in the Proc. Linn. Soc. New South Wales, 1884 , vol. ix. p. 804, has pointed out that these species were collected on the mainland of $\mathrm{New}$ Guinea itself, inland from Port Moresby. Excluding these species, there appear to be only two land-shells at present known from these islands, namely, Pupinella Brazierce, Smith, and Helix (Geotrochus) woodlarkiana, Souverbie, both of which I have above referred to.

XV.-Descriptions of Eight new Species of Chalcosiidæ. By Herbert Druce, F.L.S. \&c.

THE specimens are all in my own collection.

Trypanophora anchora, sp. $\mathrm{n}$.

Primaries and secondaries chrome-yellow with the veins, a band crossing the middle of the wing and the outer margin 